Nadiia Davydenko,

National University of Life and Environmental Sciences of Ukraine, Kyiv

Natalia Wasilewska,

Jan Kochanowski University in Kielce

Mirostaw Wasilewski,

Warsaw University of Life Science - SGGW

Olifer Ivan,

National University of Life and Environmental Sciences of Ukraine, Kyiv

\title{
THE SHADOW ECONOMY AND ITS IMPACT ON A COUNTRY'S FINANCIAL POTENTIAL
}

The aim of the article is to reveal the essence of the shadow economy and its impact on the financial potential of a country. We have discovered that the shadow economy is an objective phenomenon which is inherent in the economic systems of all countries, and that its level is determined by the level of development of the economic system, the difficulty of identifying all possible variants of the shading processes, and the moral and cultural characteristics of the country.

It has been established that the shadow economy plays a major role in developing countries and that the level of the shadow economy in advanced economies is significantly lower. Thus, due to the results of the correlation-regression analysis, an inverse relationship between the level of GDP and the shadow economy was established. A system of measures aimed at preventing and combating corruption is proposed.

Key words: shadow economy, financial potential, developing countries, advanced economies, corruption.

JEL Codes: O17

\section{Introduction}

The modern globalized world is formed of complex economic and financial processes. The spread of the shadow economy, combined with limited resources and macroeconomic imbalances, is recognized by the World Economic Forum as one of the main global risks of the future. Open borders provide for the free movement of financial resources, therefore financial flows in both directions have a shadow component. Accordingly, improving Ukraine's integration into the European Union could contribute to dynamic, transparent and civilized development. According to Ukraine, taking into account all factors, the total volume of its shadow economy is determined by up to $50 \%$ of GDP, which is one of the highest levels in the world ${ }^{1}$. This requires not only

1 Schneider F.: Shadow Economy in Turkey and in other OECD-Countries: What do we (not) know? Retrieved February 15, 2013 from http://www.gep.gov.tr/tmp/BSECpdf/Prof. Dr.FriedrichSchneiderShadEc_Turkey2012.pdf 
an adaptation of its national model of social order to European practices, but above all, that Ukraine achieve the average level of socio-economic development in European and a general parity of its regions. An uncontrolled increase in the scale of shadowing stimulates destructive processes in all sectors and spheres of the economy, contributes to the distortion of socio-economic results, and significantly hinders the implementation of qualitative reforms in the country. Therefore, an analysis of the processes of shadowing in the Ukrainian economy has not only general scientific but also practical significance, as it outlines the prospects for further development of the economy on both the national and regional level.

\section{Literature review}

In scientific research, the problem of the shadow economy first appeared in the 1930s. This was due to the presence of the Italian mafia in the American economy. However, nowadays there is no single understanding of this economic category. The lack of a common understanding of "shadow economy" determines an author's approach to its interpretation. One definition was first proposed by the American sociologist E. Feig in 1979. He defined the shadow economy as all economic activity, which for one reason or another is not taken into account by official statistics and is not included in the calculations of national accounts ${ }^{2}$. E. Feig identifies two main components of the shadow economy:

1. Economic activity that is legal, not hidden, but also that is not subject to taxation and is not taken into account by official statistics;

2. Illegal, deliberately hidden economic activity ${ }^{2}$.

Economists joined the discussion of the shadow economy in the 1970s, when the significant work of American economist P. Gutmann, "Underground Economy", was published in 1977. The author stressed the importance of establishing the causes of the shadow economy, its nature and structure, and its socio-economic consequences, and concluded that unaccounted economic activity could no longer be neglected ${ }^{3}$.

Significant scientific work on the shadow economy issue has also been conducted by V. Tanzi, who asserts that the shadow economy includes production or income that is not included in official statistics. This refers to "income not reported and not identified by the tax authorities"4. Thus, tax evasion indicates that tax authorities receive less revenue than they actually should receive. Thus, "it is implied that the country is richer than the statistics officially show". D. Thomas agrees with this approach and similarly includes in the shadow economy "those actions that are not taken into account when calculating national income"

According to institutionalism, in particular the theory of transaction costs, E. de Soto ${ }^{6}$ defines the shadow economy as a "niche for those whose costs of complying with

\footnotetext{
${ }^{2}$ Feige E.: How Big is the Irregular Economy? Challenge, 1979.

${ }^{3}$ Gutmann P.: The Subterranean Economy. Financial Analysts Journal, Vol. 33, 1977.

${ }^{4}$ Tanzi, V.: Uses and Abuses of Estimates of the Underground Economy. The Economic Journal, 109 (June), 1999.

5 Thomas J.: Quantifying the black economy: «measurement without theory» yet again? The Economic Journal, 109 (June), 1999.

${ }^{6}$. Soto E.: The other way. The invisible revolution in the third world, transl. from Engl. B. Pinsker. Moscow: Catallaxy, 1995.
} 
current legislation in carrying out economic activities exceed the benefits of achieving the intended goal." E. de Soto also analyses the qualitative assessments of legal and shadow business in the "third world" from a new perspective. According to de Soto, the main reason for the increase in the urban informal sector is "the backwardness of rural migrants, as if unable to find a place in the legal sector, and bureaucratic organization, which hinders the free development of competitive relations."

For a long time, Ukrainian scientists did not have their own scientific method in studying the problem of the shadow economy. We think that one of the first attempts to define the concept of "shadow economy" in the late twentieth century was the work of O. Turchynov, who proposed to interpret the shadow economy as an economic activity of economic entities (individuals and legal entities), which is not taken into account, controlled and taxed by official government agencies or is aimed at generating income by violating current legislation ${ }^{7}$.

Another scientist, V. Vasenko notes that the shadow economy is a "systemic phenomenon of asocial management, which is inherent in countries with any socioeconomic system, and also expresses different levels of intensity of social danger and reflects the crisis of public administration as dysfunction".

S. Mocherny believes that the shadow economy is a "sphere of economic activity aimed at obtaining income from prohibited activities or tax evasion from public (state) control and payment of taxes during the implementation of legal economic activities.",

In our opinion, the need for further meaningful consideration of the shadow economy processes results from the existence of negative influencing factors on the financial potential of the regions, which is an ascending criterion in ensuring the efficient and balanced functioning of the state.

\section{Result of scientific research}

The methodological basis of this article is a systematic approach and a set of general and specific research methods, such as: classification and systematization is used to analyze modern research in the field of economic shadowing; comparative analysis to determine the structure, causes and consequences of the shadow economy; historical tracking in order to study global trends and national characteristics of the shadow economy in the context of globalization; and generalization in the process of preparing conclusions.

It is generally understood that in any country, there is a certain part of the economy that is not taken into account with official statistics and is not under state control, such as various aspects of production, distribution, exchange and consumption of material goods $^{10 .}$

The overall level of economic shadowing in each country depends on a number of factors, including: the size of the tax burden, the degree of regulation of economic activity, the size of the public sector in the economy, the scale of the shadow labor

\footnotetext{
${ }^{7}$ Turchinov O.: Shadow economy: theoretical bases of research. Kyiv «ArtekEk», 1995

${ }^{8}$ Vasenko V.: Shadow economy of Ukraine and ways of its de-shadowing. Visnyk of Cherkasy National University. Economic Sciences Series, \#1, 2016.

${ }^{9}$ Mocherny S.: Economic Encyclopedia Vol. 3, Academy, Kyiv, 2002.

${ }^{10}$ Zaverukha M.: To determine the essence of shadow economic processes. Efficiency of public administration, Lviv, LRIDU NADU,2016.
} 
market and its regulation. However, most researchers point the laws and taxes that exist in a particular country as the main reasons for growth in the shadow economy. Among the new factors is trans-nationalization and globalization, which has a particularly negative impact on the economic development of countries with liberal economies ${ }^{11}$. In the context of globalization, E. Weiner conducted scientific research to consider the essence of the economic shadowing as a global phenomenon that extends beyond the country. He notes that "the shadow market is a group of independent wealthy countries and investors who can actually manage the world economy with instruments such as securities, real estate, currency and other financial assets that they hold in difficult regulative investment structures (hedge funds, investment funds, stabilization funds, etc.), as well as in large state-owned holding companies"12.

The shadow economy peculiarities of Ukraine include the significant connection of public administration bodies with shadow structures; the presence of "special" conditions for the functioning of individual entities; use of state property and official position to obtain illegal (shadow) income by government officials and managers; implementation of shadow operations as part of large state-owned enterprises (semiofficially);

an imperfect regulatory field, which allows for shadow operations; society's attitude to the existence of the shadow economy and corruption, as part of the norms of life, which has a system-forming nature ${ }^{13}$. In addition, an analysis of Ukrainian legislation has made it possible to draw the conclusion that many inaccuracies and contradictory statements in the legislation are preconditions for the development of corruption ${ }^{14}$.

Therefore, determining the nature and features of the shadow sector, based on research by national and foreign scientists and taking into account official statistics, we can say that today the level of the shadow economy of Ukraine is about $50 \%$ of all economic processes in the country.

It should be noted that the shadow economy exists in all countries of the world. It differs only in volume, structure and mechanisms of development. The scale and features of the shadow economy in different countries and regions of the world are closely linked to national economic models and the degree of market relations maturity. For example, according to various estimates, in developed countries the shadow economy is $12-16 \%$ of GDP; in developing countries, from 23 to $25 \%$ of GDP; in countries with economies in transition, 30-50\% of GDP. Thus, in the most developed countries the share of the shadow sector in the national economy is much smaller than in other groups of countries ${ }^{15}$.

An estimation of the shadow economy in different countries based on the MIMIC model is shown in Figure 1. The model exploits the associations between observable

\footnotetext{
${ }^{11}$ Feige E.: The Underground economies. Tax evasion and information distortion, Cambridge University Press, 2007.

${ }^{12}$ Weiner E.: Hidden power. How rich states and influential investors control the whole world, Moskwa Alpina Business Book, 2012.

${ }^{13}$ Kosmarova N.: Shadow economy in EU countries. Current issues of international relations (part II), 2013.

${ }^{14}$ Wasilewska N., Kaminska T.: Preconditions of land relations development: economic, legal and institutional. Zeszyty Naukowe SGGW, Polityki Europejskie, Finanse i Marketing [t.20(69)], 2018.

${ }^{15}$ Medina L. and Schneider F.: Shadow Economy Around the World: What did we learn over the last 20 years, International Monetary Fund, 2018.
} 
causes and effects of the unobserved informal economy to estimate the size of the informal economy itself ${ }^{16}$.

However, developed countries are not the same, and among them there are countries with fairly high rates of shadow activity. Austria, the United States, Switzerland and Japan have the lowest relative share of the shadow sector (at 8-10\% of GDP). The motivation of shadow activity in developed countries is mainly due to the excessive tax burden on enterprises and the over-regulation of economic relations ${ }^{17}$.

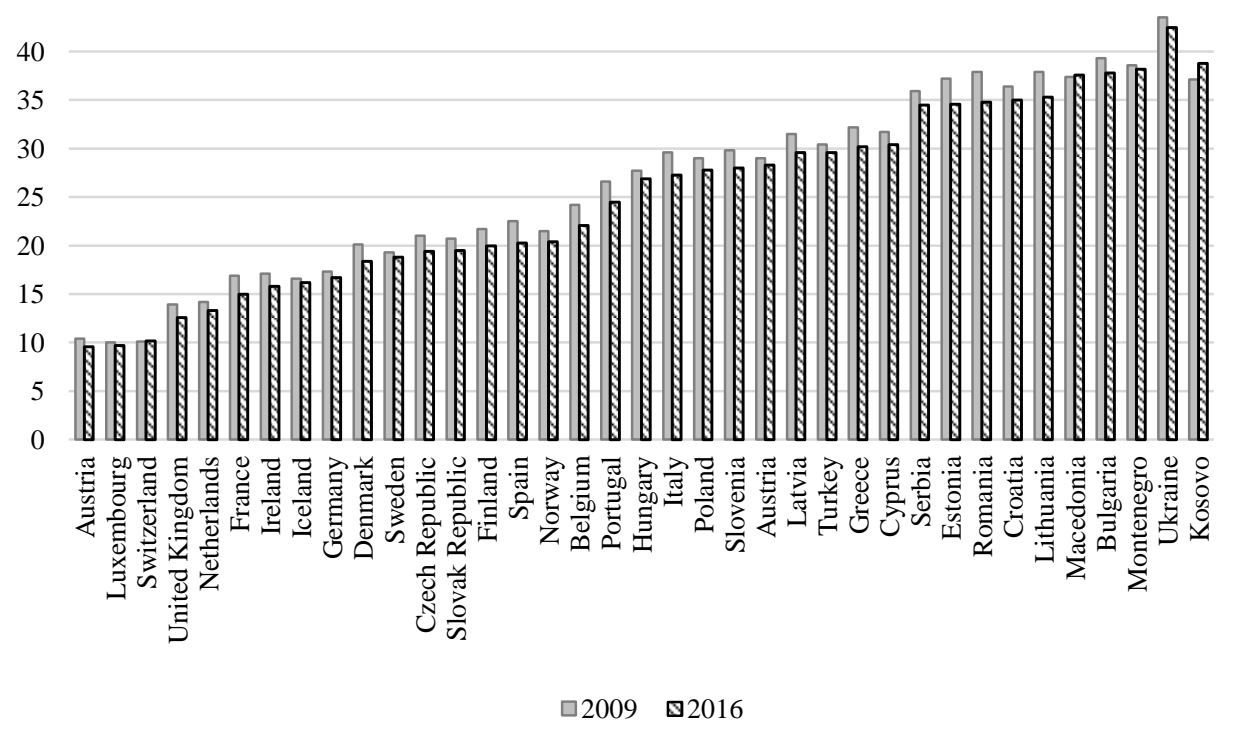

Figure 1. The size of the shadow economy in European countries, $\%$ Source: compiled by the authors based on ${ }^{18}$.

The level of the shadow economy in more developed countries is relatively low. The hidden economy has a negative correlation with per capita income based on the analysis in different countries and in different time periods (Figure 2).

When calculating the correlation-regression analysis of GDP per capita changes in the level of the shadow economy, we identified the following dependence:

$$
\mathrm{y}=-0,2851 \mathrm{x}+29,228
$$

Thus, if the level of the shadow economy increases by 1 level, GDP per capita will decrease by 0.29 . The correlation between the shadow economy and economic indicators is generally in line with expectations. There is a positive link between the shadow

\footnotetext{
${ }^{16}$ Loayza, N. The economics of the informal sector: a simple model and some empirical evidence from Latin America. The World Bank, 1999.

${ }^{17}$ Ponomorenko T., Olvinska J.: Comparative analysis of the shadow economy of the world. Statistics an instrument of socio-economic research: a collection of scientific student works, Issue 2, Odessa, ONEU, 2016.

${ }^{18}$ Kelmanson B., Kirabaeva K., Medina L., Mircheva B.: Explaining the shadow economy in Europe: size, causes and policy options, International Monetary Fund, 2019.
} 
economy and unemployment, corruption, and agriculture. The ratio between the underground economy and GDP per capita, loans to the private sector, income levels, and human development is negative.

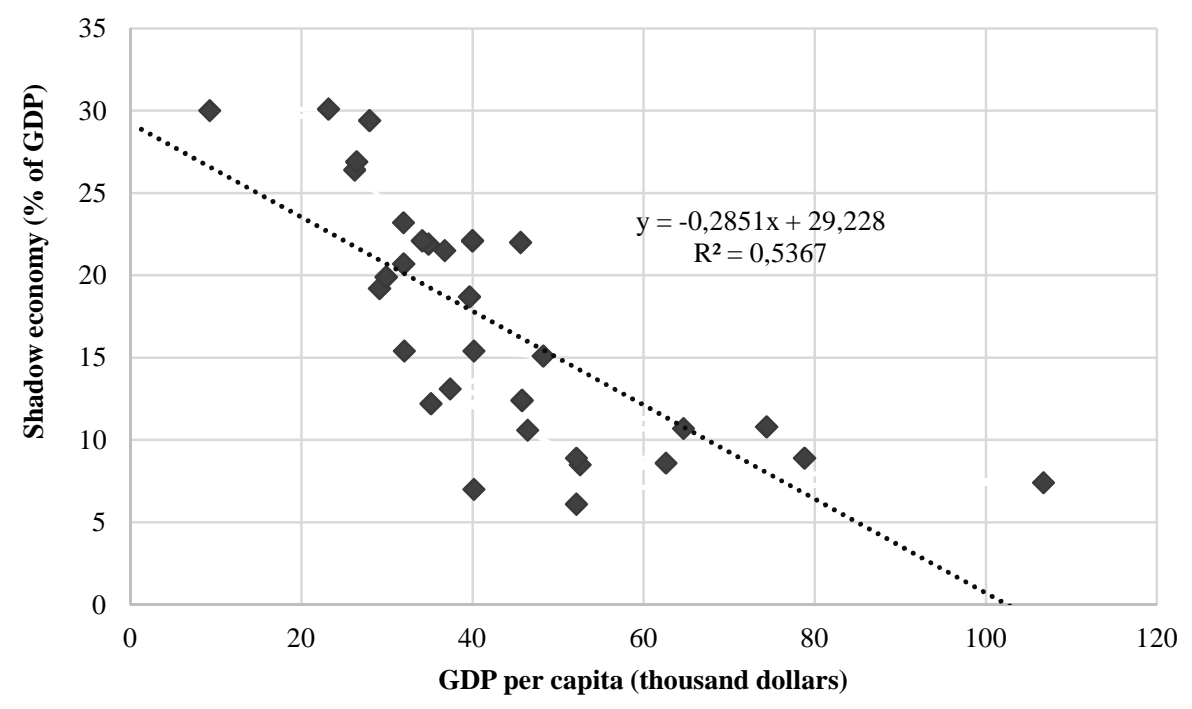

Figure 2. Shadow economy to GDP per capita, correlation-regression analysis, 2017

Source: compiled by the authors based on ${ }^{19}$.

Examining the factors that contribute to the shadow economy in developed countries, in the EU, Professor F. Schneider identified the factors presented in Table 1 and the degree of their impact ${ }^{20}$.

Table 1. Factors contributing to shadow economy development in developed countries

\begin{tabular}{|c|c|c|}
\hline \multirow{2}{*}{ Factors contributing to shadow economy growth } & \multicolumn{2}{|c|}{ Degree of influence, $\%$} \\
\hline & & (b) \\
\hline Increasing the tax burden and the amount of social security contributions & $35-38$ & $45-52$ \\
\hline Quality of state institutions & $10-12$ & $12-17$ \\
\hline Transfers & $5-7$ & $7-9$ \\
\hline Labor market regulation & $7-9$ & $7-9$ \\
\hline Public services & $5-7$ & $7-9$ \\
\hline Taxpayer morale & $22-25$ & \\
\hline Influence of all factors & $84-98$ & $78-96$ \\
\hline
\end{tabular}

(a) the average values obtained in 12 studies

(b) average values obtained in 22 studies

Source: compiled by the authors based on ${ }^{21}$

\footnotetext{
${ }^{19}$ Medina L. and Schneider F.: Shadow Economy Around the World: What did we learn over the last 20 years, International Monetary Fund, 2018.

${ }^{20}$ Schneider F. The Shadow Economy in Europe, Austria, 2013.
} 
According to F. Schneider, the growth of the tax burden and the size of social security contributions has the maximum impact on the economy shadowing in the EU with a share of $35-52 \%$.

Compared with individual countries, the contrasting trend of developed countries in terms of the shadow economy is that a larger share of the shadow economy arises due to the large number of informal workers and due to the small number of opportunities for employment on a formal basis.

According to the Ministry of Economic Development, the shadow sector of the national economy of Ukraine is quite significant: in 2010 it accounted for $38 \%$ of the country's GDP, in 2011-2012 it decreased to 34\%, in 2013 it amounted to $35 \%$, in 2015 it increased to $40 \%$, and in 2018 it decreased to $30 \%$ (Figure 3 ).

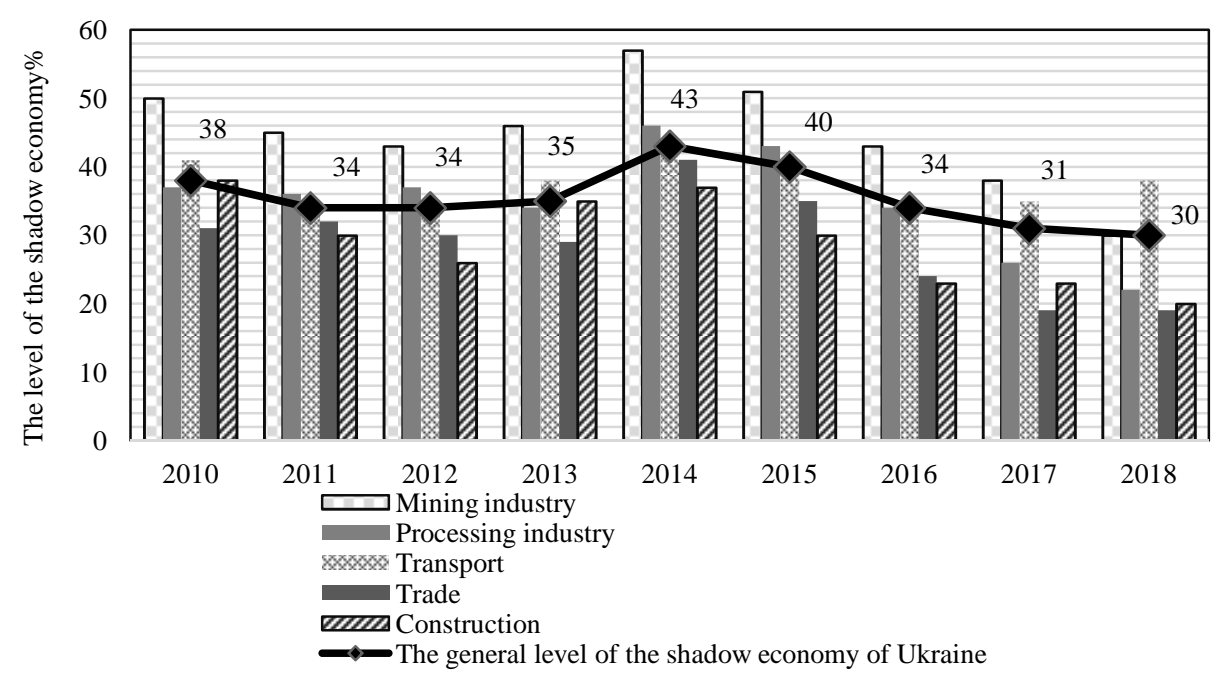

Figure 3. The level of the shadow economy of Ukraine by type of economic activity (2010-2018), \%

Source: compiled by the authors based on the reports of the Ministry of Economic Development and Trade of Ukraine.

By type of economic activity, first place is traditionally occupied by households, whose level of the shadow economy in the period 2010-2018 averages $51 \%$, while the lowest level of the shadow economy was found in agriculture $-13.1 \%$; the level of the shadow economy in extractive industries on average for 9 years was $44.8 \%{ }^{22}$.

As the trends of the general level of the shadow economy in Ukraine do not coincide with the trends of the shadow economy by types of economic activity and the level of the shadow economy of households, there is a significant differentiation of the shadow economy, so it is advisable to calculate the financial potential of the regional

\footnotetext{
${ }^{21}$ Schneider F.: Size and Development of the Shadow Economy of 31 European and 5 other OECD Countries from 2003 to 2015: Different Developments. Journal of Self - Governance and Management Economics, 3(4), 2015.

22 based on the reports of the Ministry of Economic Development and Trade of Ukraine.
} 
indicators of the shadow economy separately by type of economic activity, rather than the national level.

According to the analysis, we trace a directly proportional inverse relationship between the indicators: due to the financial crisis during 2010-2014, the level of the shadow economy ranged from $38 \%$ to $43.5 \%$. In total, from 2011 to 2015 , the level of the shadow economy increased by $6 \%$ and amounted to $40 \%$ of the country's GDP, which in hryvnia equivalent amounted to UAH 572,111 million. From 2015 to 2018, the level of the shadow economy decreased by $15 \%$ and amounted to $30 \%$ of GDP, which is in hryvnia equivalent 925022.7 million UAH (Figure 4).

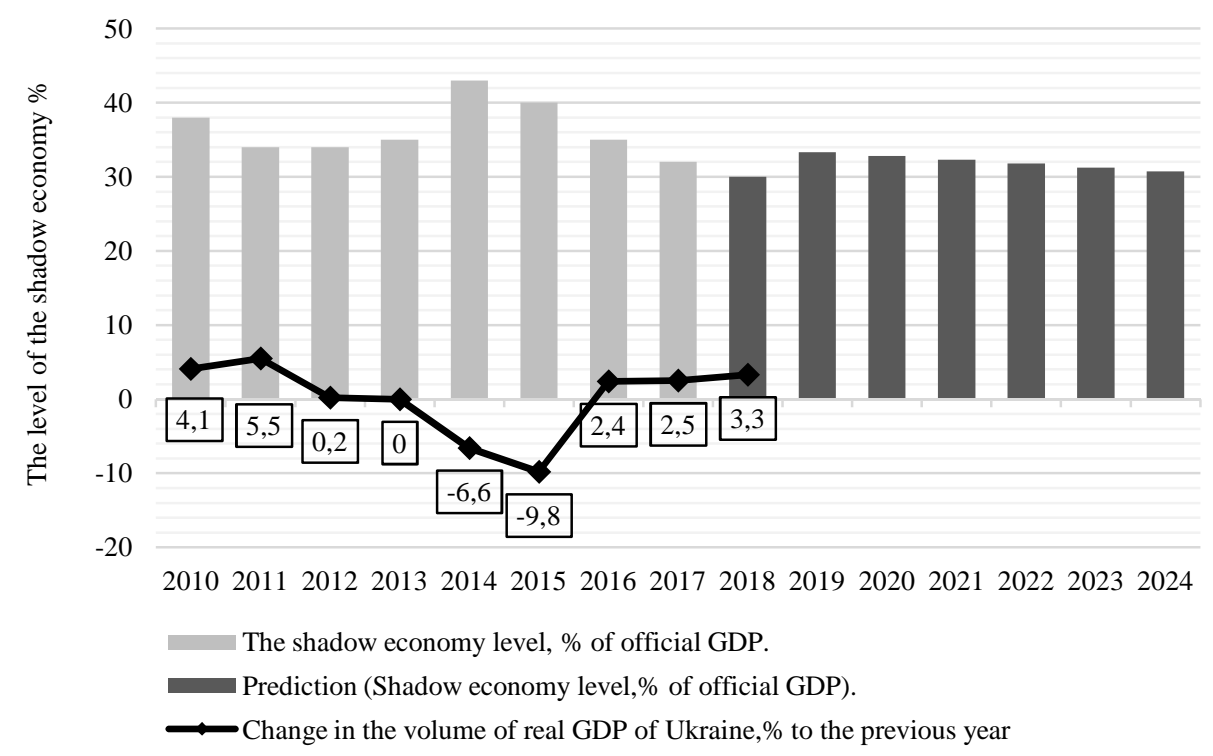

Figure 4. Integrated indicator of the level of the shadow economy and the forecast in Ukraine (in\% to GDP) Source: compiled by the authors based on the reports of the Ministry of Economic Development and Trade of Ukraine.

According to the forecast, the level of the shadow economy during 2020-2024 will range from $31-33 \%$ of the volume of official GDP. It is difficult to predict, but it is possible to trace a pattern - and to conclude that the crisis will lead to an increase in the level of the shadow economy. Given that in the domestic market there is a need to obtain funds to cover the budget deficit, which, in turn, limits Ukraine in its actions and creates obligations to comply with IMF requirements, as well as the global crisis through COVID-19, we believe that the level of the shadow economy should continue to grow.

Figure 5 shows the level of the shadow economy by region of Ukraine and type of economic activity according to the survey method, according to which the size of the shadow economy is estimated on the basis of a sample survey of enterprises using microand macro-modelling, which separates the visible and hidden components of GDP. 


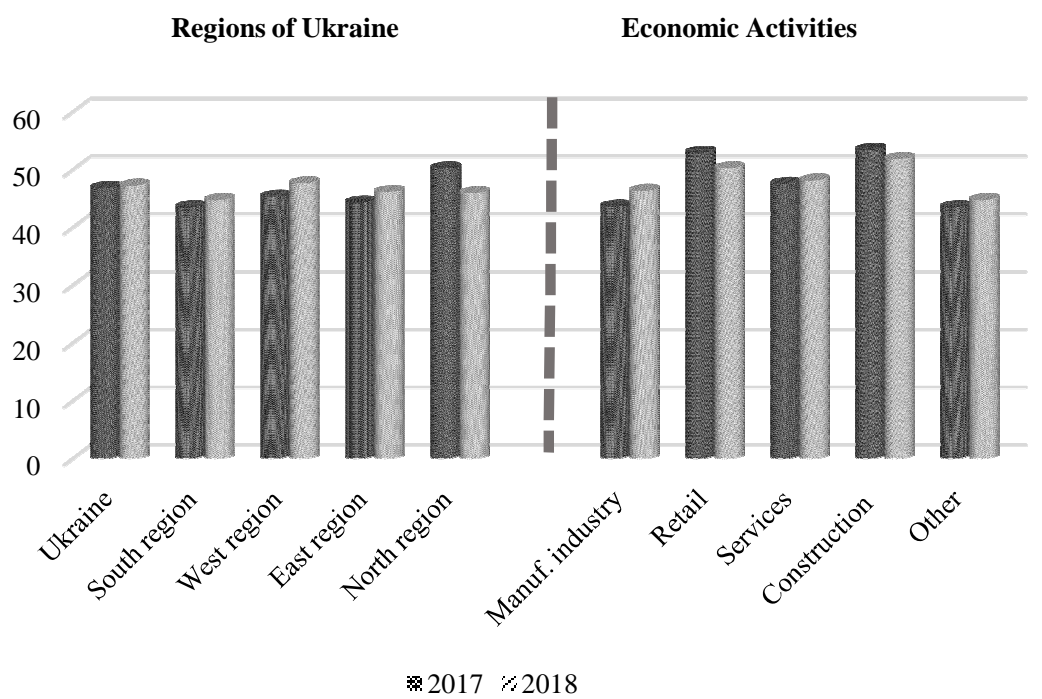

Figure 5. The level of the shadow economy in Ukraine (in\% of GDP), by regions and economic activities, \% Source: compiled by the authors based on research of Kyiv International Institute of Sociology ${ }^{23}$.

In all regions, there is an increase in the level of the shadow economy by an average of $1.5 \%$ (South - $44.7 \%$ in 2018 and $43.5 \%$ in 2017; West - $47.6 \%$ in 2018 and $43.5 \%$ in 2017; East - 46.1\% in 2018 and $44.3 \%$ in 2017, Kyiv - 45.7\% in 2018 and $44.9 \%$ in 2017) except for the North/Center, where there is a significant reduction of as much as $4.3 \%$ out of $50 \%$, and $2 \%$ in 2017 from $45.9 \%$ in 2018.

Among the main reasons for the high share of the shadow sector in the national and regional economy, we are convinced that:

1. Lack of stable business legislation and serious gaps in it, result in unsettled social and economic relations.

2. Inadequate protection of property rights.

3. Lack of historical compliance and moral standards for law-abiding behaviour of natural and legal persons, such as the payment of taxes.

4. Inefficient State regulation of the economy and high bureaucracy.

5. The prevalence of corruption in all spheres of public life, political and economic.

6. Imperfections in monetary regulation, which consist in overcharging the NBU rate, adopting a flexible exchange rate (instead of pegging to a stable currency, such as the euro), issuing government bonds with interest in favour of creditors.

7. Inadequacy of the fiscal policy of the State (inefficient administration of taxes and customs payments, legal insecurity of taxpayers, lack of effective mechanisms to punish non-compliance with tax laws).

8. Weak monitoring of the use of budgetary resources, in particular by the Ukrainian Court of Accounts.

\footnotetext{
${ }^{23}$ The shadow economy in Ukraine. The results of the 2019 study. Kyiv International Institute of Sociology.
} 
9. Growing problems in the labour market (rising unemployment, low economic incentives for formal employment of workers) and lack of an effective system to monitor and sanction informal employment and wage non-participation.

10. Long-term socio-economic crisis in the country (collapse of industry, low profitability of business, impoverishment of the majority of the population).

\section{Conclusion}

A corrupt economy in any country of the world is unable to function properly because corruption prevents the natural laws of the economy from operating freely. As a result, corruption in the political and economic operations of a State causes the impoverishment of its entire society.

According to the type of economic activities in Ukraine during 2010-2018, on average the shadow economy was found in $51 \%$ of households, $13.1 \%$ in agriculture and $44.8 \%$ in extractive industries.

As a result of the conducted research, it was found that the reduction of the shadow economy could be achieved by:

1. Intensification of consumer demand in the legal sectors of the economy (protection of the domestic market from foreign producers, increase in the share of production to create high value-added high-tech products, innovative modernization of leading industries);

2. Creating mechanisms for the transformation of capital from the shadow sector to the legal sectors of the economy (development of the stock market and improvement of the payments and customs legislation);

3. Improving competitiveness (increasing the share of local budgets, limiting monopoly power and improving the effectiveness of public authorities in competition protection);

4. Creating a favourable investment climate. In addition, reducing tax losses should be a key determinant and can be achieved by providing additional motivation and incentives for opening up businesses (tax system simplification, progressive rates, etc.).

The complexity of the problems of the shadow economy provides, to some extent, an opportunity to stimulate solutions these problems. In particular, solving legal problems should help solve social and economic problems and improve overall business conditions. Optimizing the actions of businesses can lead to an increase in attractiveness of the business climate and investment opportunities, which in turn can help ensure the financial sustainability of enterprises. This, in turn, would allow businesses to provide more reliable social security and other benefits to employees, thus reducing the perceived benefits to working in the shadows and reducing participation in the shadow economy.

\section{Reference}

Davydenko N.: The impact of the shadow economy on the financial potential of the regions. Problems and prospects of financial system development in modern conditions: collection of materials of the II International scientific-practical Internet conference, Poltava, PUET, 2020. 
Feige E.: The Underground economies. Tax evasion and information distortion, Cambridge University Press, 2007.

Feige E.: How Big is the Irregular Economy? Challenge, 1979.

Gutmann P.: The Subterranean Economy. Financial Analysts Journal, Vol. 33, 1977.

Kosmarova N.: Shadow economy in EU countries. Current issues of international relations (part II), 2013.

Loayza, N. The economics of the informal sector: a simple model and some empirical evidence from Latin America. The World Bank, 1999.

Mazur I.: De-shadowing of the economy of Ukraine: theory and practice, VPTs "Kyiv University", 2006.

Medina L. and Schneider F.: Shadow Economy Around the World: What did we learn over the last 20 years, International Monetary Fund, 2018.

Mocherny S.: Economic Encyclopedia Vol. 3, Academy, Kyiv, 2002.

Ponomorenko T., Olvinska J.: Comparative analysis of the shadow economy of the world. Statistics - an instrument of socio-economic research: a collection of scientific student works, Issue 2, Odessa, ONEU, 2016.

Schneider F.: Dimensions of the Shadow economy, The Independent Review, V. 5, \#1, Oakland, CA, 2000.

Schneider F., Klinglmair R.: Shadow Economies on the Rise Around the World. What do we know? Discussion Paper No. 1043, Bonn, 2004.

Schneider F.: Size and Development of the Shadow Economy of 31 European and 5 other OECD Countries from 2003 to 2012 Some New Facts. https://www.researchgate.net/publication/268185661_Size_and_Development_of_the_Shadow_Ec onomy_of_31_European_and_5_other_OECD_Countries_from_2003_to_2012_Some_New_Facts Schneider F. The Shadow Economy in Europe, Austria, 2013. http://feelingeurope.eu/Pages/Shadow_Economy_in_Europe.pdf

Schneider F.: Shadow Economy in Turkey and in other OECD-Countries: What do we (not) know? Retrieved February 15, 2013 from http://www.gep.gov.tr/tmp/BSECpdf/Prof. Dr.FriedrichSchneiderShadEc_Turkey2012.pdf

Schneider F.: Size and Development of the Shadow Economy of 31 European and 5 other OECD Countries from 2003 to 2015: Different Developments. Journal of Self - Governance and Management Economics, 3(4), 2015.

Soto E.: The other way. The invisible revolution in the third world, transl. from Engl. B. Pinsker. Moscow: Catallaxy, 1995. https://www.e-reading.club/bookreader.php/53846/De_Soto_Inoy_put.htm

Tanzi, V.: Uses and Abuses of Estimates of the Underground Economy. The Economic Journal, 109 (June), 1999.

The shadow economy in Ukraine. The results of the 2019 study. Kyiv International Institute of Sociology. https://www.kiis.com.ua/?lang=eng\&cat=reports\&id=897\&page=1

Thomas J.: Quantifying the black economy: «measurement without theory» yet again? The Economic Journal, 109 (June), 1999.

Turchinov O.: Shadow economy: theoretical bases of research. Kyiv «ArtekEk», 1995.

Vasenko V.: Shadow economy of Ukraine and ways of its de-shadowing. Visnyk of Cherkasy National University. Economic Sciences Series, \#1, 2016.

Wasilewska N., Kaminska T.: Preconditions of land relations development: economic, legal and institutional. Zeszyty Naukowe SGGW, Polityki Europejskie, Finanse i Marketing [t.20(69)], 2018. Weiner E.: Hidden power. How rich states and influential investors control the whole world, Moskwa Alpina Business Book, 2012.

Zaverukha M.: To determine the essence of shadow economic processes. Efficiency of public administration, Lviv, LRIDU NADU,2016. 


\section{Szara strefa i jej wpływ na potencjał finansowy kraju}

\section{Streszczenie}

Celem opracowania jest określenie istoty szarej strefy i jej wpływu na potencjał finansowy kraju. Stwierdzono, że szara strefa jest zjawiskiem obiektywnym, nieodłącznym dla systemów gospodarczych wszystkich krajów. Poziom szarej strefy jest determinowany stopniem rozwoju systemu gospodarczego, trudnością w zidentyfikowaniu wszystkich możliwych wariantów procesów w jej ramach oraz moralnością, a nawet kulturą charakteryzującą dany kraj.

Ustalono, że szara strefa odgrywa istotną rolę w krajach rozwijających się, natomiast jej poziom w gospodarkach rozwiniętych jest znacznie niższy. Na podstawie wyników analizy korelacjiregresji ustalono odwrotną zależność między poziomem PKB a wielkością szarej strefy. Zaproponowano system środków mających na celu zapobieganie i zwalczanie korupcji.

Słowa kluczowe: szara strefa, potencjał finansowy, kraje rozwijające się, gospodarki rozwinięte, korupcja.

JEL Codes: O17

Information about the authors:

Prof. Nadiia Davydenko,

National University of Life and Environmental Sciences of Ukraine, Department of Finance Heroiv Oborony Str., 10, 03-041 Kyiv, Ukraine

e-mail: davidenk@ukr.net

ORCID: 0000-0001-7469-5536

Prof. Natalia Wasilewska,

Jan Kochanowski University in Kielce,

Department of Economics and Finance

Stefana Żeromskiego Str.5, 25-369 Kielce

e-mail: nwasilewska@ujk.edu.pl

ORCID: 0000-0001-8638-4735

Prof. Mirosław Wasilewski,

Warsaw University of Life Sciences - SGGW,

Department of Finance,

Nowoursynowska Str.166, 02-787 Warszawa

e-mail: miroslaw_wasilewski@sggw.pl

ORCID: 0000-0001-6791-5713

\section{Mgr. Olifer Ivan}

National University of Life and Environmental Sciences of Ukraine,

Department of Finance

str. Heroiv Oborony, 10, 03-041 Kyiv, Ukraine 